\title{
Cécile Black
}

1976-2012

Cécile Black gjorde sig i de sidste syv år af sit alt for korte liv gældende i København som leder af den Franske Bogcafé i Fiolstræde og litteraturformidler med en fornem sans for den nyeste franske og frankofone litteratur. Det lykkedes hende med stort personligt engagement at etablere, hvad der blev et veritabelt litteraturcenter. Bøgerne fandt ved hendes indsats vej til mange læsere, som i Cécile mødte en saglig formidler og smittende inspirator. Cécile viste som få, at den levende litteraturudveksling kan lykkes, når man investerer sig selv personligt i den.

Hun udtalte selv herom $i$ et interview:

"Det betyder meget for mig at kæmpe i det daglige for læselysten, at forsvare samtidslitteraturen: en levende litteratur, der er en fornyelse. Nutidens forfattere kan appellere til mange forskellige personer, ikke kun et fransk eller frankofont publikum. Jeg har mødt mange mennesker, der har et tilhørsforhold til Frankrig og det franske sprog, og jeg blev klar over, at de mangler et samlingssted, der ikke skulle være et offentligt rum som en ambassade eller et institut, men et andet sted, der både indeholdt kulturen og litteraturen. Det viste sig, at en boghandel var et godt udgangspunkt, men det skulle være mere end blot en boghandel. Det var ikke nok at gå ind og købe en bog og så gå ud igen. Med en bogcafé kunne vi skabe en stemning, der fik bøgerne til at leve."

I november 2012 udgav Cécile Black en bog med forfatterinterviews, Philippe Claudel, Tahar Ben Jelloun, Eric-Emmanuel Schmitt og andre, som hun præsenterede således: "Jeg udvælger de forfattere, der har besøgt caféen, og har internationalt eller i det mindste europæisk spændvidde. Jeg tror virkelig, at de har noget at sige og lære danskerne. Ideen er, at det skal være tosproget, en udgave beregnet til undervisning."

Det blev en vigtig, årligt tilbagevendende begivenhed, når Bogcaféens litteraturpris blev uddelt. Bl.a. Laurent Mauvignier og Philippe Claudel har modtaget den for deres måde at tale om krig på og om mennesket og menneskets håb. Litteraturprisen var højdepunktet i hendes virke. Den styrkede forbindelsen mellem Institut français i København, den internationale forfatterscene i Diamanten og den voksende kreds af læsere, der kom i Bogcaféen. Den var en fejring af nye og spændende forfattere - og gav os andre lejlighed til at fejre Cécile selv og hendes uvurderlige indsats. Vi er mange, der har været så lykkelige at have kendt hende. Vi er lige så mange, der har beundret hende som menneske. Den inspiration, der udgik fra hende, er umistelig, men mennesket Cécile er det ikke muligt at erstatte.

Lisbeth Verstraete Hansen, Steen Bille Jørgensen, Hans Peter Lund Société danoise de littérature contemporaine en langue française 